\title{
COVID-19 and Digital Education: A Catalyst for Change?
}

\author{
Tom Crick \\ Swansea University (thomas.crick@swansea.ac.uk) \\ ORCID: 0000-0001-5196-9389
}

\begin{abstract}
While there are a huge number of challenges still facing education, there may be some light at the end of the tunnel, writes Tom Crick MBE FBCS, Professor of Digital Education \& Policy at Swansea University. Building on recent work across research, policy and practice, he analyses the rapid shift to online learning, teaching and assessment, and what this might mean for learners and educators into 2021 and beyond...
\end{abstract}

The enforced closure of educational institutions from March 2020 as a consequence of the COVID-19 global pandemic resulted in a rapid shift to "emergency remote teaching" and a move to online learning, teaching and assessment (LT\&A) [7]. The COVID-19 crisis has magnified the contribution of digital technologies in education, with a renewed focus on what tools and infrastructure are required to deliver online LT\&A at scale, and how learners and educators are able to meaningfully engage with these approaches, especially if this becomes the "new abnormal".

The general impact and efficacy of educational technology (edtech) is still unclear in formal academic literature, and is obscured by variation of educational setting, LT\&A context, and practitioner confidence and capability [6]. While a range of international research studies has shown the benefits of the successful application of digital LT\&A across a variety of contexts and settings, the widespread adoption, implementation and evaluation of edtech has yet to be fully realised [3]. Moreover, critical studies of technology's role in enhancing LT\&A are wrapped in wider concerns regarding the selling, automating and globalising of education in the digital age, more so during an era of 'pandemic politics' [9]. This is in the context of recent UK government policy commitments to 'realise the potential of technology in education [in England]', as well as promoting the UK edtech sector as a whole [5].

Perhaps more importantly, it is also reigniting a wider debate on what digital competencies learners and educators should have and should be able to apply to their broader education and practice, along with supporting young people's engagement with an increasingly digital society, culture and economy. As an example, these digital education themes have been keenly observed in Wales; since 2015, Wales has been undergoing profound changes to its education system, including a new cross-curricular Digital Competence Framework for learners ages 3-16, and a new bilingual national curriculum published in January 2020 [8]. Alongside the diverse societal and cultural drivers, there are also clear economic imperatives in raising the prominence of digital competencies, underpinning aspirations for the future economy of Wales. However, there are still issues in reconciling these significant changes to digital education policy and practice in Wales (and indeed, across the UK and internationally), especially in the emerging societal context of 'online harms' and 'fake news', and increased awareness of the impact of 'digital poverty'. And while the rapid shift to online LT\&A has brought to the fore important debates around the role of technology in education, Al, 
algorithmic governance, and the use and abuse of young people's personal data [9], there is still a lack of focus on what this means for learners.

Building on our major international survey conducted in in the immediate aftermath of the first lockdown in March 2020 and the shift to online delivery [7,2], we reflect on what this means for UK computer science education (and educators), across all settings. This directly links to the significant changes to computer science curricula, qualifications and practice across the UK in recent years [1], as well as the emerging focus on the required digital skills and infrastructure to support the UK's post-COVID economic renewal [4]. It is clear that the academic discipline of computer science - and indeed the wider information technology sector - has much to offer to address the wider challenges resulting from the COVID-19 pandemic; from computational modelling, the use of Al, machine learning and big data, as well as framing the wider legal, social, ethical and professional issues from contact tracing, personal data storage/sharing, and the widespread use of image recognition and surveillance.

We identified how those teaching computer science across various UK settings show significantly more positive attitudes towards the move to online LT\&A than those working in other disciplines; these perceptions were consistent across schools, colleges and higher education institutions. However, whilst educators noted the opportunities of these changes for their respective sector - especially with a renewed focus on the importance of digital skills - they raised a number of concerns on the impact of this shift to online on their roles, their institutions and their sectors as a whole; for example, the impact on their health and wellbeing, workload, and job fragility [7]. There were concerns raised regarding pedagogy and practice, the challenges of rapidly re-designing learning and assessments, understanding the impact on the social aspects of learning, as well as the inability to effectively deliver core computer science topics such as programming, group projects, and lab-based modules. Educators also raised significant concerns for their learners and the impact of the pandemic on specific communities and demographics, especially in identifying and addressing inequity of access and ability to meaningfully engage with online LT\&A [2].

So what does this mean for learners and educators going forward, looking ahead into 2021 and beyond? It is clear that academic lives are in transition. The nature of education has changed and will likely continue to change. Public expectations - and entitlements - have shifted. The physical closure of schools, colleges and university campuses by the COVID-19 pandemic has almost overnight changed "how we do what we do" as educators, and the nature of our daily routines. We have been forced to abandon our places of work and formally reconstitute ourselves as home workers. We have - many of us - also simultaneously become home-schoolers and/or home-carers. We no longer hold "normal" office hours; these have been radically extended. Our administrative load has become gargantuan. We are concerned about our students. We are anxious that our students have become disengaged with online LT\&A. We are worried about their mental health and wellbeing. We are feeling the strain of their demands. We are concerned about how well we can attend to their pastoral needs. We are concerned that many of our non-traditional students will drop out. Our worklife balance has collapsed. We are worried about our own mental health and wellbeing. We are suffering from being always on call. We are struggling with digital fatigue. 
However, the rapid adoption of digital technologies for almost all activities that could previously have taken place within the physical space of an educational institution presents opportunities to rethink how many academic practices might take place in virtual environments. Will this present the dawn of a new era of open, learner-centred digital technologies, cultures and practices? These resultant shifts in culture, identity, and new demands on educational leadership and management, perhaps reshaping the post-pandemic digital structure of education, may also risk exacerbating existing inequalities in the use of digital technologies. There is thus an opportunity to meaningfully co-construct and engage with learners, to give them agency and to empower them as future digital citizens, instead of introducing "one size fits all" top-down interventions that "lock in" and provides no choice, and are ultimately done to learners, rather than with them. Moreover, a prolonged - perhaps, even permanent - shift online raises significant questions around engagement and related concerns of student recruitment, retention and progression.

But we are thankful for technology. We recognise its affordances and opportunities. We acknowledge its role in our society, culture and economy, and especially in our futures. Even if we remain acutely wary and sceptical of plans for its transformational overhaul of our learning, teaching and assessments, especially as it appears that the virus may have to be tolerated into 2021 and beyond.

\section{References}

[1] Brown, N. C. C., Sentance, S., Crick, T., \& Humphreys, S. (2014). Restart: The resurgence of computer science in UK schools. ACM Transactions on Computing Education, 14(2), 1-22. https://doi.org/10.1145/2602484

[2] Crick, T., Knight, C., Watermeyer, R., \& Goodall, J. (2020). The Impact of COVID-19 and "Emergency Remote Teaching" on the UK Computer Science Education Community. In Proc. of UKICER'20. https://doi.org/10.1145/3416465.3416472

[3] Conrads, J., Rasmussen, M., Winters, N., Geniet, A., \& Langer, L. (2017). Digital education policies in Europe and beyond: Key design principles for more effective policies. European Commission, Joint Research Centre. https://ec.europa.eu/jrc/en/publication/eur-scientificand-technical-research-reports/digital-education-policies-europe-and-beyond-key-designprinciples-more-effective-policies

[4] Davenport, J. H., Crick, T., \& Hourizi, R. (2020). The Institute of Coding: A UniversityIndustry Collaboration to Address the UK's Digital Skills Crisis. In Proc. of EDUCON'20. https://doi.org/10.1109/EDUCON45650.2020.9125272

[5] Department for Education [DfE]. (2019). Realising the potential of technology in education: A strategy for education providers and the technology industry. https://www.gov.uk/government/publications/realising-the-potential-of-technology-ineducation 
[6] Education Endowment Foundation [EEF]. (2019). Using digital technology to improve learning. https://educationendowmentfoundation.org.uk/tools/guidance-reports/usingdigital-technology-to-improve-learning/

[7] Watermeyer, R., Crick, T., Knight, C., \& Goodall, J. (2020). COVID-19 and digital disruption in UK universities: Afflictions and affordances of emergency online migration. Higher Education. https://doi.org/10.1007/s10734-020-00561-y

[8] Welsh Government. (2020). Curriculum for Wales. https://hwb.gov.wales/curriculum-forwales

[9] Williamson, B., Eynon, R., \& Potter, J. (2020). Pandemic politics, pedagogies and practices: Digital technologies and distance education during the coronavirus emergency. Learning, Media and Technology, 45(2), 107-114. https://doi.org/10.1080/17439884.2020.1761641 